\title{
EXPORT COMPETITIVENESS OF THE SERBIAN AGRI-FOOD SECTOR ON THE EU MARKET
}

\author{
Milan Marković1 ${ }^{\text {, Bojan Krstić }}{ }^{2}$, Žarko Rađenović ${ }^{3}$ \\ *Corresponding author E-mail: bojan.krstic@eknfak.ni.ac.rs
}

A R T I C L E I N F O
Original Article
Received: 31 October 2019
Accepted: 26 November 2019
doi:10.5937/ekoPolj1904941M
UDC 339.564:338.43/.45(497.11)
(4-672EU)

Keywords:

competitiveness, foreign trade, agri-food sector, net trade index, Grubel-Lloyd index

JEL: Q17, Q18, F14

\section{A B S T R A C T}

The aim of the research is to examine the degree of competitiveness of the agri-food sector of the Republic of Serbia on the market of the European Union (EU) countries, as the most significant export market. Two partial indices were used in the analysis: the net trade index (NTI) and the Grubel-Lloyd index (GLI). In addition to these indicators, unit export and import price analysis was also used to obtain data on the type of competitiveness achieved by the divisions of the agri-food sector. The results show that the cereals division makes the highest contribution to reducing the existing trade deficit, while the high values of the GLI reflect a high degree of integration with this market. The agri-food sector shows dominant price competitiveness in terms of the share of such divisions in total exports to the EU. The results will include recommendations for improving the structure of exports by focusing on specific divisions.

(C) 2019 EA. All rights reserved.

\section{Introduction}

In today's globalized world, countries aim to increase their exports and specialize in exporting certain products by increasing their competitiveness (Bozduman, Erkan, 2019, p. 160). At the macroeconomic level, competitiveness is often viewed through the prism of a country's success in placing goods on the international market. The mirror of competitiveness growth is a decrease in import dependency and an improvement in the export structure (Mitrović, Mitrović, 2014). On the other hand, for the prosperity of the economy and the achievement of economic growth, it is important to ensure the achievement of adequate results in foreign trade (Melišek, 2012, p. 450).

1 Milan Marković, PhD, Research Associate, Innovation Centre of the University of Niš, Univerzitetski trg 2, 18000 Niš, +381642885134, markovicmilan89@gmail.com, ORCID ID (https://orcid.org/0000-0002-9617-6697)

2 Bojan Krstić, PhD, Full professor, Faculty of Economics, University of Niš, Trg kralja Aleksandra Ujedinitelja 11, 18000 Niš, +381 18528 685, bojan.krstic@eknfak.ni.ac.rs, ORCID ID (https://orcid.org/0000-0003-4597-6819)

3 Žarko Rađenović, PhD, Research Assistant, Innovation Centre of the University of Niš, Univerzitetski trg 2,18000 Niš, +381638787359, zarkoradjenovic@hotmail.com, ORCID ID (https://orcid.org/0000-0002-3679-7870) 
The agri-food sector is the backbone of Serbia's export potential. It is a sector that has a significant share in the export of the Republic of Serbia, and potentials have not yet been fully utilized. With trade liberalisation and regional integration on global agri-food markets, export competitiveness and its long-term duration are crucial for prosperity of agri-food products on global markets (Bojnec, Fertö, 2017, p. 2). That is why research into the competitiveness and contribution of agri-food products to the total volume of foreign trade is of utmost importance (Maslova et al., 2019). Therefore, this paper analyses the degree of competitiveness of all sections (divisions) of the so-called agri-food sector of the Republic of Serbia on the European Union (EU) market. Previous studies have mainly dealt with the competitiveness of the agri-food sector in the overall market (Ignjatijević et al., 2014; Božić, Nikolić, 2016; Andrei et al., 2017; Jovović, Jovović, 2018; Armeanu et al, 2018), that is, in the markets of the Western Balkans and other neighbouring countries (Marković, Marjanović, 2019; Birovljev et al., 2015; Drăgoi et al., 2018 ).

The subject of the study is the analysis of the importance, degree of competitiveness and specialization of the agri-food sector in foreign trade with the EU. In the EU accession process, it is very important to strengthen the capacities in order to bring the competitiveness of the agri-food sector closer to the highly competitive European market. Adjustment to market requirements should involve changes in the export structure and production modulation in quantity, quality and competitiveness (Simonović et al., 2010 , p. 74). The research therefore aims to show the current situation, potentials and possible directions for improving the export of this sector to the EU, by looking at the external competitiveness of the respective divisions, through various indicators.

Typical indicators in the analysis of export competitiveness at the sector and division level are: the net trade index (NTI) (or net export index), the Grubel-Lloyd index (GLI), and unit export and import price analysis. The NTI is closely related to the concept of revealed comparative advantage (RCA) first studied by Balassa (1965). Since it encompasses international flows, it can be said that it is an indicator of external competitiveness of the economy (Marković, 2019, p. 56). The NTI indicates whether the country is a net exporter or a net importer. The GLI is used mainly to quantify the capacity of countries to use economies of scale (Grubel, Lloyd, 1971). It is a widely used indicator that measures the volume of intra-industry (intra-sectoral) trade (Lee, 2004, p. 3 ). In the theory of international trade, intra-industry trade implies commodity exchange of differentiated products within the same statistical sectors (Petrović, 2005, p. 116). In contrast, there is inter-industry trade when a country exports goods belonging to one sector and imports goods from another sector (Milutinović, 2015, p. 36). It should be noted that the gains from intra-industry trade are generally higher than those resulting from inter-industry trade, as they include benefits associated with economies of scale, technological externalities, positive links with the rest of the economy, increasing yield dynamics (Gayá, Michalczewsky, 2014; Aditya, Acharyya, 2015; Henao Rodríguez et al., 2016). Both indices are indispensable tools in analysing and assessing the level of external competitiveness of the national economy and its sectors, and in particular the agri-food sector. Otherwise, all these indicators are used primarily in bilateral analyses. 


\section{Materials and methods}

Owing to the massive use of information technologies, foreign trade statistics are very accurate and easily accessible, which has enabled the dissemination of scientific research and published papers in this field (Stanojević, Kotlica, 2018, p. 24). The agrifood sector comprises 18 sections (divisions) from 4 export sectors of the economy of the Republic of Serbia according to the Standard International Trade Classification (SITC) (revision 4). The paper covers the period from 2012 to 2018, in order to analyse the recent state and tendencies in the competitiveness and trade of agri-food products with the EU, and draws on data from the Statistical Office of the Republic of Serbia.

The first partial indicator of export competitiveness that will be applied in the analysis is the NTI. This index is also referred to as the relative foreign trade balance (Matkovski et al., 2017). It is an index representing the quotient of net exports and total foreign trade in a given sector or division, and, accordingly, calculated as follows (Jefferson Institute, 2003; Bouzdman, Erkan, 2015; Božić, Nikolić, 2016):

$$
\text { NTIijt }=\frac{X_{i j t}-M_{i j t}}{X_{i j t}+M_{i j t}}
$$

Where in:

$N T I_{i j}$ - index of net trade of division $i$, country $j$,

$X_{i j}$ - value of export of division $i$, country $j$,

$M_{i j}$ - value of import of division $i$, country $j$,

$t-$ year.

The value of this index ranges from -1 to +1 . Positive values indicate the existence of competitiveness in the foreign market, while negative ones indicate external noncompetitiveness and the absence of specialization of the division. Higher index value implies higher export competitiveness. This index is often viewed as an alternative to the RCA index, which does not include import data (Božić, Nikolić, 2019). In addition to interpreting the data obtained on export competitiveness in the EU market, it is necessary to compare them with the total export market, which will serve as a specific benchmark, i.e. standard for comparison.

In addition to the NTI, the GLI is an indispensable tool in the analysis and assessment of competitiveness at the division level. It was created in 1971 by Herb Grubel and Peter Lloyd. It is an indicator that is used to determine the importance of intra-industry exchange of divisions in trade between two countries and is calculated by the following formula (Grubel, Lloyd, 1975; Clark et al., 2001; Mrdalj, 2015):

$$
\text { GLIijt }=1-\frac{\left|X_{i j t}-M_{i j t}\right|}{X_{i j t}+M_{i j t}}
$$


This is the most commonly used form of this index in empirical research, which is also used in structural compliance or export matching analyses. The index has been modified to analyse at the division level and its value indicates the degree of presence of the division in intra-sectoral foreign trade (Milićević et al., 2017, p. 140).

If the value of this indicator is 1 , then there is no inter-industry trade. This would mean that the country simultaneously exports and imports the same type of product. In this case, the entire export/import of a particular section is cancelled by the import or export of the same division. If the GLI is zero, then there is no intra-industry, but only inter-industry exchange. Then the country only exports or imports a certain type of product, so only inter-industry (cross-sector) trade is realized. Higher index values indicate a higher degree of specialization in intra-industry trade, while lower values imply that foreign trade is closer to inter-industry trade (Raičević et al., 2012, p. 210). Higher values of the GLI make it possible to exploit the economies of scale effect due to the higher degree of integration with a particular market, enable specialization within certain sectors, as well as adjusting to market conditions at lower costs (because of the ease of reallocation of production resources within the same sector).

The GLI shows the ability to compete with a particular country with competition, as well as the degree of integration of a particular sector, division or commodity group with a particular market (Birovljev et al., 2015). Higher values speak to the complementarity of economies. However, some limitations in the application of this index have been noted in practice. Brülhart (1994) states that the GLI is mercantilist in nature, while the relationship between exports and imports does not provide complete information on competitiveness and overall adjustment costs. The same author emphasizes the greater importance of exploring "dynamic" flows, i.e. structures of change in the flow of goods.

An analysis based on the comparison of export and import values, on the one hand, and unit prices of exports and imports, on the other, completes the research on export competitiveness. Depending on whether there are higher values of exports or imports, as well as on the basis of a comparison of unit export prices $\left(\mathrm{Px}_{\mathrm{ij}}=\mathrm{X}_{\mathrm{ij}} / \mathrm{Qx_{ij }}\right)$ and unit import prices $\left(\mathrm{Pm}_{\mathrm{ij}}=\mathrm{M}_{\mathrm{ij}} / \mathrm{Qm}_{\mathrm{ij}}\right)$, useful information on the type of external competitiveness in the market is obtained (in this case in the EU market), which is explained by the following relationships (Jefferson Institute, 2006; Marković, Marjanović, 2019):

i) $\mathrm{Px}_{\mathrm{ij}}>\mathrm{Pm}_{\mathrm{ij}}$ Ù $\mathrm{X}_{\mathrm{ij}}>\mathrm{M}_{\mathrm{ij}} \mathrm{P}$ quality competitiveness,

ii) $\mathrm{Px}_{\mathrm{ij}}<\mathrm{Pm}_{\mathrm{ij}}$ Ù $\mathrm{X}_{\mathrm{ij}}>\mathrm{M}_{\mathrm{ij}} \mathrm{P}$ price competitiveness,

iii) $\mathrm{Px}_{\mathrm{ij}}>\mathrm{Pm}_{\mathrm{ij}}$ Ù $\mathrm{X}_{\mathrm{ij}}<\mathrm{M}_{\mathrm{ij}}$ P price non-competitiveness, and

iv) $\mathrm{Px}_{\mathrm{ij}}<\mathrm{Pm}_{\mathrm{ij}} \mathrm{U}_{\mathrm{ij}}<\mathrm{M}_{\mathrm{ij}}$ P quality non-competitiveness.

Depending on this, the divisions of the agri-food sector will be classified into one of these four segments. Such an analysis, among other things, indirectly shows the structure of imports and exports of the agri-food sector. Lower unit export prices indicate the export of raw materials and this is characteristic of countries with low levels of agricultural and food industry development and vice versa. 


\section{Results and discussions}

The EU is the most important foreign trade partner of the Republic of Serbia. This is shown by data on the EU's share in total exports, as well as in exports of agri-food products of the Republic of Serbia (Figure 1). At the same time, the percentage of EUdirected exports has been steadily increasing, while the EU's share in exports of the agri-food sector, on the other hand, has been steadily decreasing since 2012. This is one of the first signals that the export competitiveness of this sector should be increased, as the EU agri-food market is undoubtedly highly developed, with strict standards, high requirements and significant protectionist measures in the field of agriculture.

Figure 1. EU participation in the total exports and exports of the agri-food sector of the Republic of Serbia from 2012 to 2018 (in \%)

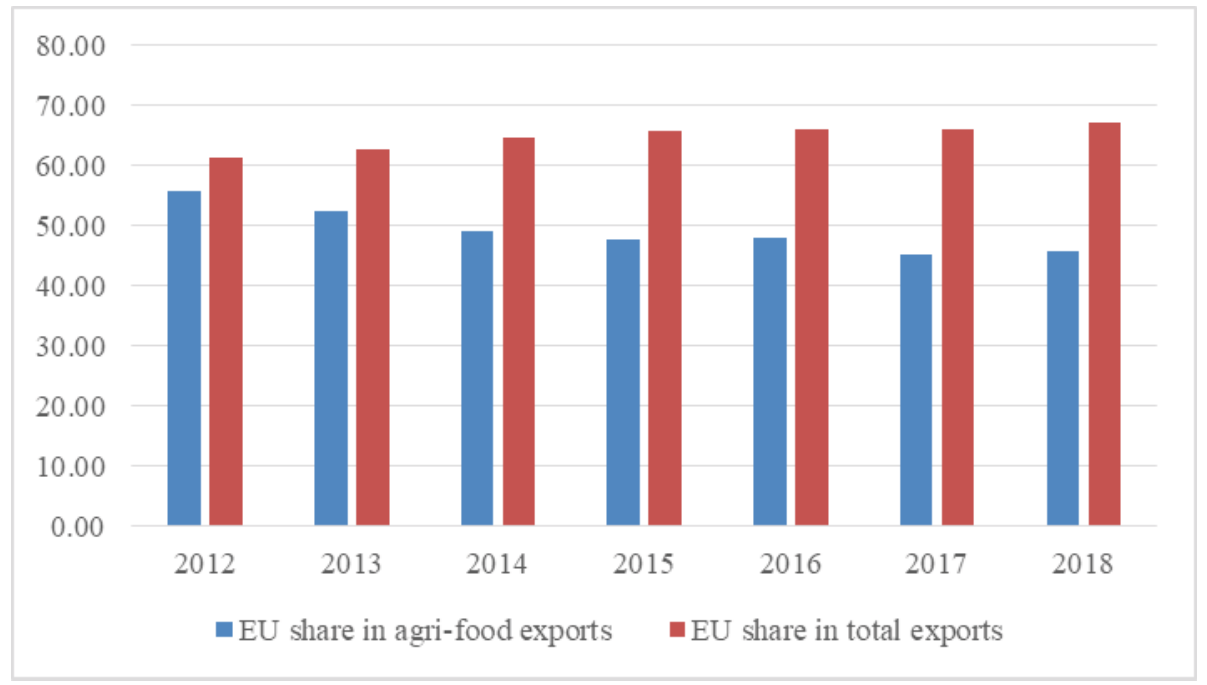

Source: Authors' calculations based on the data of the Statistical Office of the Republic of Serbia, 2019

The first in a series of indicators was the NTI of the agri-food sector with the EU. Table 1 shows the values of this index for the agri-food divisions both in the EU and world market. The analysis showed that the cereals division is the most competitive in exports both in the EU market and in the overall market, with an average NTI value of 0.71 and 0.75 , respectively. The lowest external competitiveness in the EU market is recorded by divisions covering live animals and meat and meat products. The downside is that only 7 out of 18 divisions of this sector are competitive on the EU market, while the situation with world exports of agri-food products from Serbia is more favourable given that 12 divisions achieve positive net exports and overall external competitiveness is higher compared to export competitiveness in the EU. This means that trade with the EU contributes less to reducing Serbia's permanent trade deficit. 
Table 1. NTI of the Serbian agri-food sector in trade with the EU and the world

\begin{tabular}{|l|c|c|}
\hline \multirow{2}{*}{ Divisions, by SITC rev. 4 } & \multicolumn{2}{|c|}{ NTI (average, 2012-2018.) } \\
\cline { 2 - 3 } & EU & World \\
\hline 00 Live animals other than animals of division 03 & $-0,98$ & 0,18 \\
\hline 01 Meat and meat preparations & $-0,85$ & $-0,06$ \\
\hline 02 Dairy products and birds eggs & $-0,59$ & 0,21 \\
\hline $\begin{array}{l}\text { 03 Fish, crustaceans, molluscs and aquatic invertebrates; } \\
\text { preparations }\end{array}$ & $-0,78$ & $-0,81$ \\
\hline 04 Cereals and cereal preparations & 0,71 & 0,75 \\
\hline 05 Vegetables and fruit & 0,51 & 0,39 \\
\hline 06 Sugar, sugar preparations and honey & 0,48 & 0,52 \\
\hline 07 Coffee, tea, cocoa, spices, and manufactures thereof & $-0,64$ & $-0,42$ \\
\hline 08 Feeding stuff for animals (not including unmilled cereals) & 0,10 & 0,29 \\
\hline 09 Miscellaneous edible products and preparations & $-0,45$ & $-0,03$ \\
\hline 11 Beverages & $-0,04$ & 0,39 \\
\hline 12 Tobacco and tobacco manufactures & $-0,28$ & 0,11 \\
\hline 21 Hides, skins and furskins, raw & $-0,02$ & 0,10 \\
\hline 22 Oil-seeds and oleaginous fruits & 0,24 & 0,24 \\
\hline 29 Crude animal and vegetable materials, not elsewhere specified & $-0,36$ & $-0,15$ \\
\hline 41 Animal oils and fats & $-0,51$ & $-0,33$ \\
\hline 42 Fixed vegetable fats and oils, crude, refined or fractionated & 0,50 & 0,56 \\
\hline $\begin{array}{l}\text { 43 Animal or vegetable fats and oils, processed; waxes of animal } \\
\text { or vegetable origin }\end{array}$ & 0,31 & 0,27 \\
\hline TOTAL AGRI-FOOD SECTOR & $\mathbf{0 , 1 8}$ & $\mathbf{0 , 2 9}$ \\
\hline
\end{tabular}

Source: Calculation of the authors' based on the data of the Statistical Office of the Republic of Serbia, 2019

Figure 2 compares the NTI of the agri-food sector in trade with the EU and the world, as well as overall foreign trade with the EU. In the total foreign trade with the EU, this index is negative, because in fact there is a net import. Despite the negative values, there is a constant increase in the value of this index in the total trade with the EU. The NTI of the agri-food sector with the EU is lower than the NTI of the agri-food sector with the world, especially after 2013, due to increasing imports of agri-food products from the EU. 
Figure 2. NTI in trade in agri-food products of the Republic of Serbia with the EU and the world and the NTI in total trade with the EU

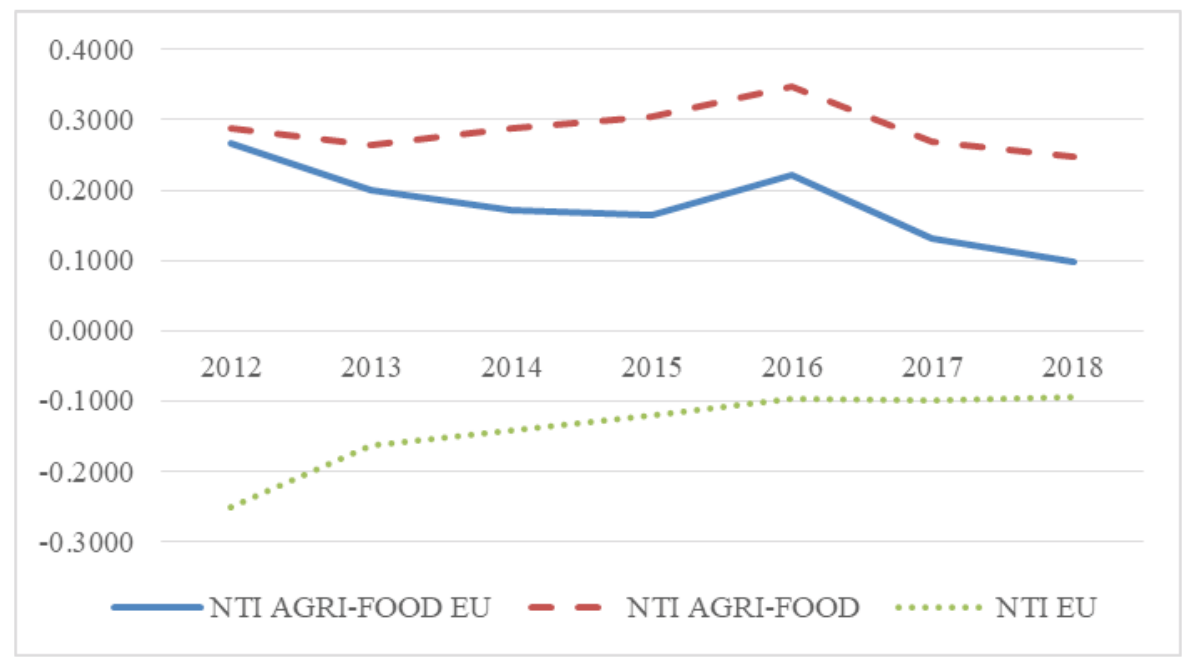

Source: Authors' calculations

In order to observe the degree of integration with the EU market in the agri-food sector, the GLI values are given in the Table 2. The analysis showed that a higher degree of connectivity is recorded with the EU market than with the whole world market. The degree of integration is by far the highest in the beverage and leather and fur divisions, which can be used to grow exports from these divisions.

Table 2. GLI values in trade of agri-food products of the Republic of Serbia with the EU and the world

\begin{tabular}{|l|c|c|}
\hline \multirow{2}{*}{ Divisions, by SITC rev. 4 } & \multicolumn{2}{|c|}{ GLI (average, 2012-2018.) } \\
\cline { 2 - 3 } & EU & World \\
\hline 00 Live animals other than animals of division 03 & 0,02 & 0,73 \\
\hline 01 Meat and meat preparations & 0,15 & 0,91 \\
\hline 02 Dairy products and birds eggs & 0,41 & 0,79 \\
\hline $\begin{array}{l}\text { 03 Fish, crustaceans, molluscs and aquatic invertebrates; } \\
\text { preparations }\end{array}$ & 0,21 & 0,19 \\
\hline 04 Cereals and cereal preparations & 0,29 & 0,24 \\
\hline 05 Vegetables and fruit & 0,49 & 0,61 \\
\hline 06 Sugar, sugar preparations and honey & 0,51 & 0,48 \\
\hline 07 Coffee, tea, cocoa, spices, and manufactures thereof & 0,36 & 0,58 \\
\hline 08 Feeding stuff for animals (not including unmilled cereals) & 0,88 & 0,71 \\
\hline 09 Miscellaneous edible products and preparations & 0,55 & 0,95 \\
\hline 11 Beverages & 0,96 & 0,61 \\
\hline 12 Tobacco and tobacco manufactures & 0,72 & 0,81 \\
\hline
\end{tabular}




\begin{tabular}{|l|c|c|}
\hline \multirow{2}{*}{ Divisions, by SITC rev. 4 } & \multicolumn{2}{|c|}{ GLI (average, 2012-2018.) } \\
\cline { 2 - 3 } & EU & World \\
\hline 21 Hides, skins and furskins, raw & 0,93 & 0,90 \\
\hline \multirow{2}{*}{ Divisions, by SITC rev. 4 } & \multicolumn{2}{|c|}{ GLI (average, 2012-2018.) } \\
\cline { 2 - 3 } & EU & World \\
\hline 22 Oil-seeds and oleaginous fruits & 0,71 & 0,72 \\
\hline 29 Crude animal and vegetable materials, not elsewhere specified & 0,64 & 0,85 \\
\hline 41 Animal oils and fats & 0,49 & 0,67 \\
\hline 42 Fixed vegetable fats and oils, crude, refined or fractionated & 0,50 & 0,44 \\
\hline $\begin{array}{l}\text { 43 Animal or vegetable fats and oils, processed; waxes of animal } \\
\text { or vegetable origin }\end{array}$ & 0,69 & 0,73 \\
\hline TOTAL AGRI-FOOD SECTOR & $\mathbf{0 , 8 2}$ & $\mathbf{0 , 7 1}$ \\
\hline
\end{tabular}

Source: Calculation of the authors' based on the data of the Statistical Office of the Republic of Serbia, 2019.

Graph 3 gives a comparative overview of the GLI in the foreign trade of the agri-food sector with the EU and the world as well as the total trade of all sectors with the EU. The highest degree of integration is recorded in total trade with the EU, and in the agrifood sector there is a greater degree of integration with the EU than with the world as a whole. Due to the extremely high complementarity between the agriculture of Serbia and the EU, an increase in exports and specialization could be significant in the future.

Figure 3. GLI in the trade of agri-food products of the Republic of Serbia with the EU and the world, as well as in the overall trade with the EU

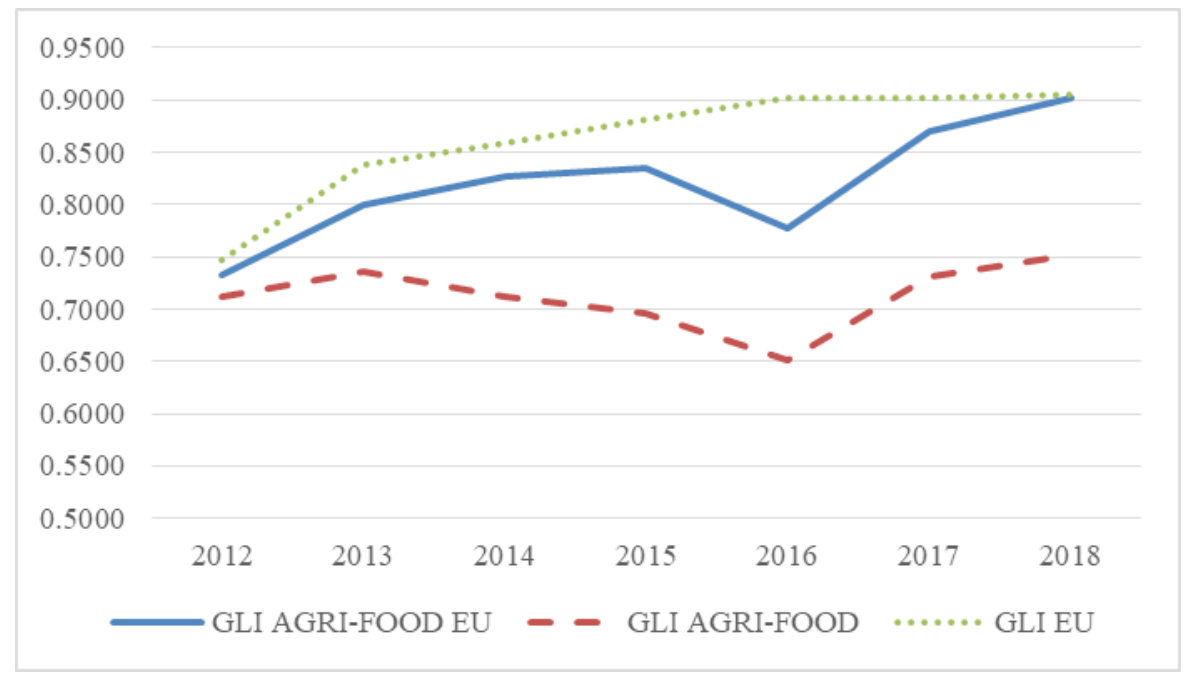

Source: Authors' calculations

Finally, Table 3 presents an analysis of the competitiveness (non-competitiveness) factors, by comparing export and import prices with the values of exports and imports 
of the agri-food divisions on the EU market. The data showed that non-price factors of competitiveness were dominant, since most of the divisions show this type of noncompetitiveness. Fortunately, the average share of such divisions in total exports of agri-food products to the EU is only $13.55 \%$. The positive fact is that the vegetable and fruit division, which is the most significant section in terms of the average annual value of exports, is competitive with quality in the EU market. In addition, the division of cereals, which, by the average value of exports lags very slightly behind the said section, also records competitiveness, but of a different type, i.e. price competitiveness.

Table 3. Factors of competitiveness of the divisions of agri-food products of the Republic of Serbia in the EU market and average participation in the export to the EU

\begin{tabular}{|l|l|c|}
\hline $\begin{array}{l}\text { Divisions of the agri-food sector, by SITC rev. } \\
\mathbf{4}\end{array}$ & $\begin{array}{l}\text { Price/non-price } \\
\text { (non) competitiveness }\end{array}$ & $\begin{array}{l}\text { Average } \\
\text { participation in } \\
\text { the EU agri-food } \\
\text { export }\end{array}$ \\
\hline $\begin{array}{l}\text { 00 Live animals other than animals of division } \\
\text { 03 }\end{array}$ & Price non-competitiveness & 0,02 \\
\hline 01 Meat and meat preparations & Price non-competitiveness & 0,54 \\
\hline 02 Dairy products and birds eggs & Quality non-competitiveness & 0,94 \\
\hline $\begin{array}{l}\text { 03 Fish, crustaceans, molluscs and aquatic } \\
\text { invertebrates; preparations }\end{array}$ & Price non-competitiveness & 0,35 \\
\hline 04 Cereals and cereal preparations & Price competitiveness & 29,03 \\
\hline 05 Vegetables and fruit & Quality competitiveness & 30,50 \\
\hline 06 Sugar, sugar preparations and honey & Price competitiveness & 7,60 \\
\hline $\begin{array}{l}\text { 07 Coffee, tea, cocoa, spices, and manufactures } \\
\text { thereof }\end{array}$ & Quality non-competitiveness & 1,39 \\
\hline $\begin{array}{l}\text { 08 Feeding stuff for animals (not including } \\
\text { unmilled cereals) }\end{array}$ & Price competitiveness & 5,07 \\
\hline $\begin{array}{l}\text { 09 Miscellaneous edible products and } \\
\text { preparations }\end{array}$ & Quality non-competitiveness & 3,42 \\
\hline 11 Beverages & Quality non-competitiveness & 3,64 \\
\hline 12 Tobacco and tobacco manufactures & Quality non-competitiveness & 2,78 \\
\hline 21 Hides, skins and furskins, raw & Price non-competitiveness & 1,66 \\
\hline 22 Oil-seeds and oleaginous fruits & Price competitiveness & 5,06 \\
\hline $\begin{array}{l}\text { 29 Crude animal and vegetable materials, not } \\
\text { elsewhere specified }\end{array}$ & Quality non-competitiveness & 1,23 \\
\hline 41 Animal oils and fats & Quality non-competitiveness & 0,15 \\
\hline $\begin{array}{l}\text { 42 Fixed vegetable fats and oils, crude, refined } \\
\text { or fractionated }\end{array}$ & Price competitiveness & 6,37 \\
\hline $\begin{array}{l}\text { 43 Animal or vegetable fats and oils, processed; } \\
\text { waxes of animal or vegetable origin }\end{array}$ & Price competitiveness \\
\hline
\end{tabular}

Source: Calculation of the authors' based on the data of the Statistical Office of the Republic of Serbia, 2019 
However, according to the share of exports, dominated by a group of divisions that achieve price competitiveness. Their average share in total agri-food exports to the EU is $53.40 \%$. Divisions from a segment that achieves price non-competitiveness in the EU market should be translated into a segment that captures price competitiveness by increasing production efficiency or reducing transport costs (Jefferson Institute, 2006). The divisions with the highest unit export prices are live animals, fish and tobacco, so these sections should have greater support in the restructuring of this sector.

\section{Conclusions}

The EU is the most important foreign trade partner of the Republic of Serbia, both in terms of total exports (on average, over the survey period, $65 \%$ of exports are directed to the EU) and exports of agri-food products (49\% of agri-food exports are exported to EU countries), and is undoubtedly a significant market for the Republic of Serbia. In the current circumstances, increasing the value of exports and achieving longterm competitiveness will increasingly be based on export restructuring and product differentiation, rather than an increase in export volumes. The aim of the research was to analyse the competitiveness of the agri-food sector in foreign trade with the EU in order to find new directions for increasing the value of exports, which ultimately means changing (improving) the production-export structure.

The results of the research showed that the agri-food sector as a whole is competitive in exports to the EU market, bearing in mind that the NTI is positive and stands at 0.18. However, it is a low level of competitiveness that is lower and compared to the total trade of agri-food products to the world. Due to the increasing imports of agri-food products from the EU, the value of the NTI has been steadily decreasing, except in 2016. Cereals and vegetables and fruits represent parts of the agri-food sector, accounting for close to $60 \%$ of agri-food exports and achieving the highest levels of the NTI. On the other hand, live animals and meat show the lowest competitiveness in the EU market. According to the value of the GLI, the export potential could be divisions of beverages and leather and fur, since the costs of adapting to the EU market conditions when it comes to these divisions would be the lowest. In terms of competitiveness type, quality competitiveness is dominant in the EU market. Only the vegetable and fruit division of the EU market competes with quality, so production and export should be further favoured. In addition, it is necessary to work on improving the quality of the products obtained and increasing the degree of their processing where possible. Although cereals exercise price competitiveness, it is necessary to increase the absolute value of exports and this division, while live animals, fish and tobacco products could have significant export potential due to the very high unit price of exports achieved.

\section{Acknowledgements}

The paper is a part of the research done within the project number 179066 ("Improving the Competitiveness of the Public and Private Sector by Networking Competences in the European Integration Process of Serbia") and project number 43014 ("Improvement of 
the monitoring system and the assessment of a long-term population exposure to pollutant substances in the environment using neural networks"), financed by the Ministry of Education, Science and Technological Development of the Republic of Serbia.

\section{Conflict of interests}

The authors declare no conflict of interest.

\section{References}

1. Aditya, A., \& Acharyya, R. (2015). Trade liberalization and export diversification. International Review of Economics \& Finance, 39, 390-410. https://doi. org/10.1016/j.iref.2015.07.007

2. Andrei, J. V., Mieila, M., \& Panait, M. (2017). The impact and determinants of the energy paradigm on economic growth in European Union. PloS one, 12(3), e0173282. https://doi.org/10.1371/journal.pone.0173282

3. Armeanu, D., Vintilă, G., Andrei, J. V., Gherghina, Ş. C., Drăgoi, M. C., \& Teodor, C. (2018). Exploring the link between environmental pollution and economic growth in EU-28 countries: Is there an environmental Kuznets curve?. PloS one, 13(5), e0195708. https://doi.org/10.1371/journal.pone.0195708

4. Balassa, B. (1965). Trade liberalization and revealed comparative advantage. Manchester: The Manchester School of Economics and Social Studies Journal, 33(2), 99-123. https://doi.org/10.1111/j.1467-9957.1965.tb00050.x

5. Birovljev, J., Matkovski, B., \& Ćetković, B. (2015). The competitiveness of the Serbian agri-food products on the market of countries in the region. Annals of the Faculty of Economics in Subotica, 51(33), 61-78. [in Serbian: Бировљев, J., Матковски, Б., \& Ћетковић, Б. (2015), Конкурентност пољопривреднопрехрамбених производа Србије на тржишту земаља региона. Анали Економског факултета у Суботици].

6. Bojnec, Š., \& Fertö, I. (2017). The duration of global agri-food export competitiveness. British Food Journal, 119(6), 1378-1393. https://doi.org/10.1108/ BFJ-07-2016-0302

7. Bozduman, E. T., \& Erkan, B. (2019). Sectoral Competitive Advantages in Kazakhstan's Foreign Trade as a Rising Star of Central Asia, 7th SCF International Conference on "The Future of the European Union and Turkey-European Union Relations”, Usak/Turkey, 11-13th April 2019, 160-168.

8. Božić,D.,\&Nikolić,M.(2016). Characteristics ofSerbianforeigntrade ofagricultural and food products. Marketing, 47(4), 293-304. [in Serbian: Božić, D., \& Nikolić, M. (2016), Obeležja spoljnotrgovinske razmene poljoprivredno-prehrambenih proizvoda Srbije. Marketing]. https://doi.org/10.5937/markt1604293B

9. Božić, D., \& Nikolić, M. (2019). Foreign trade and comparative advantages of agrarian sector of Serbia and neighbouring countries. Economics of Agriculture, 66(3), 737-753.

10. Brülhart, M. (1994). Marginal intra-industry trade: measurement and relevance for the pattern of industrial adjustment. Review of World Economics, 130(3), 600-613. 
11. Clark, D. P., Fullerton Jr, T. M., \& Burdorf, D. (2001). Intra-industry trade between the United States and Mexico: 1993-1998. Estudios económicos, 167-183.

12. Drăgoi, M. C., Andrei, J. V., Mieilă, M., Panait, M., Dobrotă, C. E., \& Lădaru, R. G. (2018). Food Safety and Security in Romania-An Econometric Analysis in the Context of National Agricultural Paradigm Transformation. Amfiteatru Economic, 20(47), 134-150.

13. Gayá, R., \& Michalczewsky, K. (2014). South American Intra-regional trade: export pattern and intra-industry flows, Washington: Inter-American Development Bank. [en español: Gayá, R., \& Michalczewsky, K. (2014), El comercio Intrarregional sudamericano: patrón exportador y flujos intraindustriales. Washington: Banco Interamericano de Desarrollo]. Retrieved from http://www.iadb.org/ (September 30, 2019)

14. Grubel, H. G., \& Lloyd, P. J. (1971). The Empirical Measurement of Intra- Industry Trade. Economic Record, 47(120), 494-517. https://doi. org/10.1111/j.1475-4932.1971.tb00772.x

15. Grubel, H. G., \& Lloyd, P. J. (1975). Intra-industry trade. The theory and measurement of international trade in differentiated products. 19, 71-117. London.

16. Henao Rodríguez, C., Lis Gutiérrez, J. P., Viloria, A., \& Laverde, H. (2016). Synthesis of the Indices used to Measure Intra-industry Trade. International Journal of Control Theory and Applications. 9(44), 427-434.

17. Ignjatijević, S., Čavlin, M., \& Đorđević, D. (2014). Measurement of comparative advantages of processed food sector of Serbia in the increasing the export. Economics of Agriculture, 61(3), 677-693. https://doi.org/10.5937/ekoPolj1403677I

18. Jefferson Institute (2003). Competitiveness of Serbian economy [in Serbian: Džeferson institut (2003), Konkurentnost privrede Srbije]. Retrieved from https:// www.nbs.rs/internet/latinica/90/90 0/konkurentnost_privrede srbije.pdf

$(23$ October, 2019)

19. Jefferson Institute (2006). Competitiveness of Serbian economy [in Serbian: Džeferson institut (2006), Konkurentnost privrede Srbije]. Retrieved from https:// issuu.com/jeffersoninstitute/docs/konkurentnostweb 1 (19 October, 2019)

20. Jovović, D., \& Jovović, D. (2018). Competitiveness of food manufacturing of Republic of Serbia. Economics of Agriculture, 65(1), 49-64. https://doi.org/10.5937/ ekoPolj1801049J

21. Lee, H. (2004). Regime Selection as an Alternative to Grubel Lloyd Index. Seoul: Konkuk University.

22. Marković, M. (2019). Analysis of comparative advantages of Serbian exports at the sectoral level. Ekonomika, 65(3), 55-64. https://doi.org/10.5937/ ekonomika1903055M

23. Marković, M., Marjanović, I. (2019). Export competitiveness of Serbian agri-food sector in the Western Balkan countries. In Krstić, B. (Ed). Improving Macroeconomic Competitiveness - Thematic collection of papers of international significance. Niš: Faculty of Economics, University of Niš, 79-97. 
24. Maslova, V., Zaruk, N., \& Avdeev, M. (2019, May). The impact of the competitiveness of Russian agri-food products on the dynamics of Russian foreign trade. In IOP Conference Series: Earth and Environmental Science (Vol. 274, No. 1). IOP Publishing. https://doi.org/10.1088/1755-1315/274/1/012026

25. Matkovski, B., Lovre, K., \& Zekić, S. (2017). The foreign trade liberalization and export of agri-food products of Serbia. Agricultural Economics (Czech Republic), 63(7), 331-345. https://doi.org/10.17221/345/2015-AGRICECON

26. Melišek, I. (2012). Measurement and evaluation of macroeconomic results of foreign trade. Economic Review, 41(4), 439-451. [in Slovak: Melišek, I. (2012), Meranie a hodnotenie makroekonomických výsledkov zahraničného obchodu. Ekonomické rozhl'ady].

27. Milićević, S., Nikolić, M., \& Cvetanović, S. (2017). The competitiveness of wood processing industry in the Republic of Serbia during the period 19952015. Industrija, 45(3), 131-150. https://doi.org/10.5937/industrija45-14579

28. Milutinović, S. (2015). The importance of intra-industry trade in the contemporary world economy. Economics: Theory and Practice, 8(1), 35-46. [in Serbian: Milutinović, S. (2015), Značaj intra-industrijske trgovine u savremenoj svetskoj privredi. Ekonomija: teorija i praksa]. https://doi.org/10.5937/etp1501035M

29. Mitrović, V., \& Mitrović, I. (2014). Raising of competitiveness of export-oriented industries: Economic priorities of national importance. Ekonomika, 60(3), 263283. [in Serbian: Митровић, В., \& Митровић, И. (2014), Подизање нивоа конкурентности извозно оријентисане индустрије - економски приоритет од националног значаја. Економика].

30. Mrdalj, V. (2015). The Competitiveness of Agroindustry Sector of the Republic of Srpska in International Trade. Agro-knowledge Journal, 16(1), 21-31. [in Serbian: Mrdalj, V. (2015), Konkurentnost agroindustrijskog sektora Republike Srpske u međunarodnoj razmjeni. Agroznanje]. http://dx.doi.org/10.7251/ AGRSR1501021M

31. Petrović, P. (2005). Structural characteristics of trade between Serbia and the European Union. Economic Annals, 166, 109-128. [in Serbian: Petrović, P. (2005), Strukturne karakteristike robne razmene Srbije i Evropske unije. Ekonomski anali].

32. Raičević,V.,Ignjatijević,S.,\&Matijašević,J.(2012).Economicandlegaldeterminants of export competitiveness of the food industry of Serbia. Industrija, 40(1), 201-226.

33. Simonović, Z., Cvijanović, D., \& Hamović, V. (2010). The role of agrarian sector in economic growth of Serbia. Ekonomika, 56(4), 73-82.

34. StatisticalOffice of the Republic ofSerbia(2019). Foreign TradeDatabase. [inSerbian: Републички завод за статистику (2019), База података о спољној трговини], Retrieved from https://data.stat.gov.rs/Home/Result/170302?languageCode $=$ srCyrl (October 18, 2019)

35. Stanojević, N., \& Kotlica, S. (2018). Globalization and methodology of researches in international trade. Industrija, 46(2), 21-38. https://doi.org/10.5937/ industrija46-15888 
